\title{
Mirosław Marczak
}

Politechnika Koszalińska

e-mail: miromilan@wp.pl

\section{BRANDING OBSZARU RECEPCJI TURYSTYCZNEJ I JEGO WYKORZYSTANIE W DZIALANIACH NARODOWYCH ORGANIZACJI TURYSTYCZNYCH}

\section{BRANDING OF TOURIST RECEPTION AREA AND ITS USE IN THE ACTIVITIES OF NATIONAL TOURISM ORGANIZATIONS}

DOI: $10.15611 / \mathrm{pn} .2017 .473 .30$

JEL Classification: L83, M31

Streszczenie: W ciągu ostatnich dwóch dekad branding stał się istotnym elementem kształtującym podejście marketingowe polegające na współdziałaniu wielu zainteresowanych stron, które powinny współpracować z sobą w celu osiągnięcia pożądanego rezultatu w procesie zarządzania marką obszaru recepcji turystycznej (ORT). Celem głównym artykułu jest przedstawienie koncepcji brandingu ORT oraz zaprezentowanie praktycznych aspektów jej wdrażania przez narodowe organizacje turystyczne funkcjonujące na świecie. W artykule przyjęto hipotezę badawczą zakładającą, że branding stanowi bardzo ważną część działań podejmowanych przez NTO w ramach procesu zarządzania krajowym ORT pomimo faktu, że nie należy on do zadań, które można by zaliczyć do priorytetowych dla tego typu organizacji. Przeprowadzona analiza wykazała, że zdecydowana większość badanych NTO uznało działania podejmowane w ramach brandingu za jeden z kluczowych aspektów zarządzania, m.in. marką obszarów recepcji turystycznej.

Słowa kluczowe: branding, marka, destynacja turystyczna, narodowa organizacja turystyczna.

Summary: Over the two past decades, branding has become an important element that forms the marketing approach which consists in cooperation of many stakeholders who need to cooperate in order to achieve the desired result in the tourism reception area brand management process. The chief purpose of this article is to present the conception of the tourism reception area branding and to present the practical aspects of its implementation by NTO's worldwide. In the article, the research hypothesis has been accepted stating that branding constitutes a very important part of the activities undertaken by NTO as part of the tourism reception area management process, in spite of the fact that it does not constitute a part of those tasks that could be included among priorities for this type organizations. The analysis conducted demonstrated that a significant majority of the NTO's covered by the research considered actions undertaken as part of branding as one of the key aspects of the management.

Keywords: branding, brand, destination, national tourism organization. 


\section{Wstęp}

Proces zarządzania obszarem recepcji turystycznej jest niezwykle złożony. Szczególną rolę w tym względzie odgrywają narodowe organizacje turystyczne (NTO), które promując dany kraj jako atrakcyjną destynację turystyczną, odpowiadają za część tego procesu, m.in. w zakresie kreowania jego pozytywnego wizerunku turystycznego. Narodowe organizacje turystyczne realizując swoje podstawowe zadania, bardzo często wykorzystują różnego rodzaju instrumentarium. W kampaniach marketingowych oprócz klasycznych, standardowych narzędzi promocyjnych coraz częściej sięgają do instrumentów mających na celu budowanie i utrwalanie znajomości marki ORT w świadomości i percepcji potencjalnych odbiorców. Mowa tu $\mathrm{m}$.in. o brandingu, który jak wykazano w niniejszym opracowaniu, stanowi istotną część działań podejmowanych przez NTO pomimo faktu, że w założeniach nie należy on do priorytetowych zadań przypisywanych tego typu organizacjom. Tymczasem, zdaniem wielu autorów, wykorzystywanie markowych aspektów obszaru recepcji turystycznej przyczynia się do poprawy jego wizerunku turystycznego, a tym samym wzrostu konkurencyjności jego oferty. To właśnie produkty markowe funkcjonujące na danym ORT pomagają m.in. wzmocnić oraz podwyższyć tzw. atrakcyjność postrzeganą. Istotną rolę w tym względzie przypisuje się właśnie wszelkim działaniom podejmowanym w ramach brandingu.

Niniejszy artykuł w znacznej części został opracowany na podstawie badań własnych. Analizie poddano 83 narodowe organizacje turystyczne funkcjonujące na świecie. Przedmiotem analizy były m.in. działania tych organizacji podejmowane w ramach brandingu. Główną metodą badawczą wykorzystaną w opracowaniu jest metoda sondażu diagnostycznego z zastosowaniem techniki ankietowej. Narzędziem badawczym był kwestionariusz ankietowy, który w angielskiej wersji językowej został rozesłany do poszczególnych NTO za pośrednictwem mediów elektronicznych. Uzupełniającą metodę badawczą stanowi ponadto wywiad bezpośredni, który został przeprowadzony z pracownikami badanych NTO podczas targów turystycznych ITB Berlin w latach 2013-2016. Celem tego badania było m.in. zweryfikowanie informacji uzyskanych w wypełnionych kwestionariuszach ankietowych.

\section{Koncepcja marki obszaru recepcji turystycznej (ORT)}

Pojęcie marki obszaru recepcji turystycznej jest ściśle związane z ideą marketingu obszaru recepcji turystycznej (destination marketing), która to z kolei powstała m.in. w oparciu o założenia marketingu terytorialnego. Zagadnieniem tym zajmowali się liczni autorzy [m.in. Davidson, Maitland 1997; Domański (red.) 1997; Flanagan, Ruddy 2000; Girard 1997; Heath, Wall 1991; Kavaratzis, Ashworth 2008; Kotler i in. 1993; Markowski 1999; Meffert 1989; Murray 2001; Palmer, Bejou 1995; Szromnik 1997, 2002; Ward 1998]. Pojęcie to jest różnorodnie definiowane w literaturze przedmiotu. Różnice dotyczą przede wszystkim precyzyjnego określenia 
podmiotów podejmujących działania w tym względzie (np. władze samorządowe, instytucje publiczne, stowarzyszenia, przedsiębiorstwa turystyczne) oraz zakresu przestrzennego, w jakim może być wykorzystywany (np. rynek lokalny, regionalny, krajowy, międzynarodowy).

Kategoria „obszar recepcji turystycznej” (ORT) do terminologii turystycznej weszła w latach 70. XX w. [Kesić, Pavlić 2011]. Punktem wyjścia dla wielu opracowań w tym zakresie były m.in. prace R. Butlera [1980], odnoszące się do cyklu życia miejscowości turystycznej, czy też E. Inskeepa [1991], dotyczące planowania na obszarze recepcji turystycznej [Borzyszkowski 2015]. Pod koniec ubiegłego stulecia w koncepcji ORT zaczęły pojawiać się nowe aspekty, w tym m.in. wpływ funkcjonowania takich obszarów na środowisko przyrodnicze oraz wykorzystanie działań marketingowych dla celów ORT. Bardzo często w anglojęzycznej literaturze przedmiotu można spotkać inne nazewnictwo obszaru recepcji turystycznej. Jednym z takich pojęć jest „destynacja” (destination - cel podroży, miejsce przeznaczenia). Jak podają liczni autorzy [Borzyszkowski 2015, Kozioł 2012, Nowacki, Zmyślony 2012, Żemła 2003], pojęć „obszar recepcji turystycznej” oraz „destynacja” można używać zamiennie, gdyż traktowane są jako synonimy.

Według M. Dębskiego [2013] destynacja to miejsce, które przyciąga odwiedzających w celu tymczasowego pobytu. Może nią być kraj, prowincja, region, miasto czy wieś. Natomiast UNWTO uszczegóławia to podejście, wskazując, że lokalna destynacja turystyczna jest to przestrzeń, w której turysta spędza przynajmniej jedną noc, a składa się ona zarówno $\mathrm{z}$ atrakcji, jak i wszelkich usług niezbędnych do umożliwienia turyście pobytu [Ipsas 2012]. Podejście takie z pewnością jest słuszne, gdyż wskazuje na elementy składowe produktu destynacji. Z kolei A. Niezgoda [2006], podkreślając funkcjonalny charakter wydzielonego obszaru, zaznacza, że zasięg obszaru określanego jako destynacja jest różny w zależności od celu i motywu podróży.

Dokonując przeglądu współczesnych definicji obszaru recepcji turystycznej, należy podkreślić dość duże zróżnicowanie w podejściu autorów do tego pojęcia. Niemniej jednak można odnaleźć w nich kilka cech wspólnych. Jedną z nich jest z pewnością odnoszenie się przy definiowaniu ORT do bliżej nieokreślonej, fizycznej przestrzeni [Bieger 1998, Nawrocka 2008], pełniącej funkcję turystyczną [Niezgoda 2006], lub obszaru rozpatrywanego w aspekcie geograficznym, ekonomicznym oraz społecznym [Flagestad 2002], którego granice wyznaczane są przez czynniki fizyczne, polityczne i rynkowe, niezależnie od granic administracyjnych [Kotler i in. 2003]. Przestrzeń ta lub obszar może dotyczyć konkretnej gminy, regionu lub kraju [Cieślikowski, Żemła 2002, Goncalves, Aguas 1997, Pike 2004b]. Kolejną cechą wspólną jest m.in. postrzeganie obszaru recepcji turystycznej jako celu podróży turystycznej [Bieger 1998, Leiper 2004] lub jako miejsca, do którego kieruje się strumień ruchu turystycznego [Cieślikowski, Żemła 2002, Dziedzic 1998]. Część autorów [m.in. Manente, Minghetti 2006, Nawrocka 2008, Page, Connell 2009] rozpatruje natomiast obszar recepcji turystycznej w kategoriach produktu turystycznego posiadającego własną, rozpoznawalną markę [m.in. Middleton, Hawkins 1998]. 
Zarządzanie marką ORT stało się jednym z tematów najczęściej podejmowanych przez badaczy zjawiska turystyki zarówno w kraju, jak i za granicą. Marka ORT określona została jako najpotężniejsze narzędzie, jakim dysponują współcześni specjaliści od marketingu. Nie jest to jednak pojęcie jednoznacznie zdefiniowane w literaturze i wciąż budzi liczne kontrowersje. Przykładowo, pojęcie kreowania marki ORT bardzo często bywa utożsamiane z kreowaniem wizerunku ORT, co nie jest właściwe [Żemła 2009]. Jak podaje J. Borzyszkowski [2015], marka stanowi istotny element w strukturze działan marketingowych ORT. Dotyczy to przede wszystkim rozwoju tożsamości danej marki oraz jej pozycjonowania. Jak pisze dalej ten autor, można nawet pokusić się o stwierdzenie, że ma ona nieodzowny związek z konkretnym ORT. W przypadku marki ORT można mówić o nazwie, symbolu, logo lub innym elemencie graficznym, które identyfikują i odróżniają dany ORT [Ritchie, Ritchie 1998].

Obecnie ORT stały się najpotężniejszymi markami na rynku turystycznym. Ich złożoność i wielowymiarowość stanowią wyzwanie dla współczesnych marketerów i planistów [Kozak, Mazurek 2011]. Podobnie uważa D. Buhalis [2000], według którego marka ORT postrzegana jest przez turystów jako ogół dostawców oraz usług i „konsumowana” jest przez nich jako całościowe przeżycie podczas podróży. Należy również podkreślić, że proces budowy silnej marki ORT jest długotrwały i zdeterminowany wieloma czynnikami. Niemniej jednak posiadanie przez dany ORT rozpoznawalnej i silnej marki niesie z sobą wiele korzyści, wśród których według

A. Panasiuka [2014] najważniejsze to:

- wzrost świadomości i rozpoznawalności ORT;

- wzrost zainteresowania turystów danym ORT, przyczyniający się do zwiększenia ich liczby, potęgujący wykorzystanie obszaru, dający podstawę do rozwoju zagospodarowania turystycznego, a także zmniejszający skutki sezonowości;

- wzrost liczebności turystów lojalnych;

- wzrost udziału w rynku;

- poprawa konkurencyjności danego ORT;

- wzrost atrakcyjności inwestycyjnej danego ORT;

- wzrost dochodów budżetowych w jednostkach samorządu terytorialnego znajdujących się w granicach ORT;

- poprawa jakości życia mieszkańców danego ORT;

- stymulujący wpływ na inne sektory gospodarki na danym obszarze.

\section{Istota brandingu obszaru recepcji turystycznej}

Wzmożone zainteresowanie naukowców brandingiem ORT zaobserwowano na początku XXI w. Potwierdzeniem tej tezy wydaje się przegląd publikacji dokonany przez A. Morrisona [2013]. Autor ten, w oparciu o statystyki narzędzia internetowego Google Scholar, wnikliwie przestudiował literaturę naukową z lat 1970-2012, a następnie, przyjmując pięć przedziałów czasowych, podał dla każdego z nich licz- 
bę znalezionych publikacji na temat brandingu ORT (tab. 1). Badania wykazały, że rozkwit publikacji dotyczących tego zagadnienia nastąpił w ostatnich 15 latach. Ponad 99\% publikacji w tym zakresie powstało bowiem po $2000 \mathrm{r}$.

Tabela 1. Liczba publikacji z zakresu brandingu ORT w latach 1970-2012 w oparciu o statystyki Google Scholar

\begin{tabular}{|c|l|c|}
\hline Lp. & \multicolumn{1}{|c|}{ Lata } & Liczba publikacji z zakresu brandingu ORT \\
\hline 1 & $1970-1979$ & 0 \\
\hline 2 & $1980-1989$ & 1 \\
\hline 3 & $1990-1999$ & 15 \\
\hline 4 & $2000-2009$ & 1210 \\
\hline 5 & $2010-2012$ & 1300 \\
\hline 6 & Łącznie & 2526 \\
\hline
\end{tabular}

Źródło: opracowanie własne na podstawie [Borzyszkowski 2015, Morrison 2013].

Choć pojęcie brandingu funkcjonuje w literaturze przedmiotu stosunkowo od niedawna, to dość szybko zostało uznane za bardzo skuteczny sposób możliwie szybkiego uzyskania poprawy jakości, podwyższenia rangi i efektywności wybranych sektorów turystycznych. W ciągu ostatnich dwóch dekad branding stał się bardzo ważnym elementem kształtującym podejście marketingowe polegające na współdziałaniu wielu zainteresowanych stron, które powinny współpracować z sobą w celu osiągnięcia pożądanego rezultatu [Green 2005].

Interdyscyplinarność oraz wieloaspektowość tego pojęcia, a także jego rzeczywista skuteczność i efektywność rynkowa spowodowały, że zagadnieniem brandingu zajęło się wielu autorów [m.in. Aaker 1991, 1997, 2002; Anholt 2002, 2003a, 2003b, 2005, 2006, 2007, 2009, 2010; Anholt, Spaven 2009; Ashworth 2010; Boyle 2003; Cliffton, Simmons 2004; de Chernatony, McDonald 2003; Dinnie 2008; Fan 2006; Gabrielsson 2005; Govers 2009; Govers, Go 2009; Kavaratzis, Ashworth 2006; Majewski 2000, 2007, 2012; Morgan 2004; Olins 2000, 2004; Pike 2002, 2004a, 2004b, 2008, 2009; Pike, Page 2014; Richie, Richie 1998; Tesławski 2013; Żemła 2009, 2012]. Należy również podkreślić, że zainteresowanie tym zagadnieniem może wynikać m.in. z faktu, iż branding ma uniwersalny charakter. Może bowiem być wykorzystywany zarówno w odniesieniu do przedsiębiorstwa, jak i destynacji turystycznej (np. regionu czy też kraju) oraz jej produktów turystycznych. W tym drugim przypadku bardzo często spotyka się jednak stanowisko, że w pierwszej kolejności dana destynacja turystyczna powinna posiadać produkt (produkty), aby można było przystąpić do budowania świadomości marki [Majewski 2012].

W krajowej i zagranicznej literaturze przedmiotu branding jest różnorodnie definiowany. Przykładowo M. Łuczak [2010] definiuje branding jako proces projektowania, planowania, budowania i komunikowania marki - jej tożsamości, nazwy, sym- 
boliki czy wartości - w celu zbudowania reputacji i wizerunku. Znaczenie brandingu w skutecznym pozycjonowaniu marki na rynku podkreślają również S. Saraniemi i M. Ahonen [2008]. Autorki podkreślają powiązanie postrzegania przez odbiorców marki na rynku z „unikalną propozycją sprzedaży” charakteryzującą daną markę (USP, Unique Selling Proposition). Taki odbiór marki przez konsumentów mają właśnie zapewnić działania w ramach brandingu. Zbliżoną definicję podaje M. Mazurek [2008]. Według niej branding obejmuje zbiór działań marketingowych zmierzających do wykreowania odpowiedniej nazwy, symbolu, logo oraz znaku graficznego. Ich zadaniem jest zapewnienie łatwej identyfikacji danej marki na rynku oraz jej kojarzenie przez odbiorców, a także konsolidacja i wzmocnienie więzi emocjonalnej między poszczególnymi podmiotami funkcjonującymi na rynku.

Specyfika funkcjonowania brandingu została również podkreślona przez A. Rauscha [2009], który zaproponował podział działań w ramach brandingu w oparciu o trzy poziomy:

- poziom kreatywny, na którym tworzy się nowe produkty i symbole;

- poziom kierowniczy, na którym wybiera się i wprowadza na rynek nowe produkty oraz związane z nimi symbole;

- poziom komunikacji, na którym rozpowszechnia się symbole i zapewnia dotarcie informacji do odbiorców.

Nieocenioną rolę brandingu na rynku podkreśla S. Pike [2004a]. Według niego współcześni konsumenci mają do wyboru znacznie więcej produktów niż kiedykolwiek. Problem polega jednak na tym, iż nie mają zbyt dużo czasu na podjęcie właściwej decyzji. Znajomość marki ułatwia zatem podejmowanie decyzji i zmniejsza ryzyko związane z zakupem, tworzy oczekiwania dotyczące korzyści i dostarczania obietnic. Głównym celem w ramach brandingu powinno być zatem dążenie do zwiększenia wartości marki w świadomości i umysłach odbiorców.

Z kolei K. Dinnie i M. Fola [2009] podkreślają rolę brandingu w kreowaniu świadomości marki turystycznej obszarów. Ich zdaniem branding miejsca może koncentrować się zarówno na miastach, regionach, jak i całych narodach. Często postrzegany jest jako środek do różnicowania marek w oczach docelowych odbiorców i przyczynia się do osiągnięcia rozwoju gospodarczego poprzez zwiększenie eksportu, przyciągnięcie inwestycji i promocję turystyki na danym obszarze.

Rolę brandingu w budowaniu świadomości marki turystycznej obszaru podkreślają również R. Carter i M. Fabricius [2007]. Do głównych zadań na poziomie administracji rządowej zaliczają oni m.in. promocję destynacji turystycznych oraz działania w zakresie budowania świadomości marki i wizerunku danej destynacji. Należy zaznaczyć, iż dotyczy to zarówno destynacji na poziomie krajowym, jak i regionalnym [Marczak 2013].

Niezależnie od powyższych różnic $\mathrm{w}$ definiowaniu pojęcia brandingu można zauważyć szereg problemów związanych z tym zagadnieniem. Okazuje się bowiem, że m.in. w gospodarce turystycznej pojęcie brandingu nie jest jednoznaczne. Badanie w tym zakresie przeprowadzili m.in. C. Blain, S.E. Levy i J.R.B. Ritchie [2005] na 
grupie 409 Destination Management Organizations (DMO), głównie z USA i Kanady. Uzyskane wyniki jednoznacznie wskazują, że branding jest różnie interpretowany przez decydentów. Do najczęstszych sformułowań i haseł podawanych przy tym pojęciu zaliczono:

- wizerunek $(33,3 \%)$,

- rozpoznanie/identyfikacja $(21,1 \%)$,

- rozróżnianie $(17,7 \%)$,

- spójność $(15,5 \%)$,

- komunikacja $(14,4 \%)$,

- emocje gości $(11,1 \%)$,

- tworzenie oczekiwań $(11,1 \%)$.

Natomiast badania przeprowadzone wśród 43 członków Europejskiej Rady Podróży (ETC) i Światowej Organizacji Turystyki (UNWTO) w sierpniu 2008 r. wykazały, że pojęcie brandingu kojarzy się przede wszystkim:

- ze zbiorem wartości (18\%),

- $\mathrm{z}$ konkurencją tożsamości (17\%),

- $\mathrm{z}$ istotą obszaru recepcji turystycznej (17\%),

- $\mathrm{z}$ wizerunkiem (13\%),

- $z \operatorname{logo}(9 \%)$

- $z$ produktem $(7 \%)$,

- ze stylistyką (7\%),

- $\mathrm{z}$ brzmieniem $(6 \%)$,

- z kampanią marketingową (6\%) [Handbook on Tourism ... 2009].

Podsumowując dotychczasowe rozważania, można stwierdzić, że branding stanowi jedno z najważniejszych narzędzi wykorzystywanych w marketingu ORT, przyczyniając się do zwiększenia konkurencyjności między destynacjami [Pike 2005]. J. Borzyszkowski [2015] uważa jednak, że nie należy traktować brandingu jako lekarstwa na wszystkie problemy związane z rozwojem i promocją obszarów recepcji turystycznych. Podobnego zdania jest A. Tan [2008], według którego branding nie jest w stanie zadowolić każdego. Co więcej, autor ten uważa, że jeżeli próbuje się to zrobić, to efekty nie są zadowalające.

\section{Wykorzystanie brandingu przez badane narodowe organizacje turystyczne (NTO)}

Przeprowadzona analiza wykazała, że obecnie na świecie funkcjonuje 111 typowych NTO działających na szczeblu krajowym, realizujących główne zadania przypisane tego typu organizacjom (m.in. promocja danego kraju jako atrakcyjnej destynacji turystycznej). Należy do nich zaliczyć 46 krajowych organizacji typu NTO działających w Europie oraz 65 NTO funkcjonujących na pozostałych kontynentach. Ostatecznie w procesie badawczym uczestniczyło 83 NTO (75,0\% ich ogólnej liczby), z czego 39 (47,0\%) funkcjonuje w Europie, natomiast pozostałe 44 (53,0\%) na 
innych kontynentach (Ameryka - 17,0\%, Afryka - 12,0\%, Azja i Pacyfik - 20,5\%, Bliski Wschód $-3,5 \%)^{1}$. Taki rozkład geograficzny analizowanych NTO pozwolił również na przyjęcie głównego podziału badanych podmiotów na dwie grupy: organizacje funkcjonujące w Europie oraz organizacje funkcjonujące na pozostałych kontynentach (tzw. reszta świata). Zamierzeniem autora było m.in. wykazanie różnic i cech wspólnych w podejściu europejskich i pozaeuropejskich NTO do kwestii brandingu. Podsumowując, do dalszej analizy przyjęto: 39 NTO funkcjonujących w krajach europejskich, 14 funkcjonujących na terenie obu Ameryk, 10 działających w Afryce, 17 funkcjonujących w Regionie Azji i Pacyfiku oraz 3 NTO na Bliskim Wschodzie.

Uzyskane wyniki badań potwierdziły przyjętą w artykule hipotezę badawczą zakładającą, że branding stanowi bardzo ważną część działań podejmowanych przez NTO w ramach procesu zarządzania obszarem recepcji turystycznej na szczeblu krajowym pomimo faktu, że nie należy on do zadań, które można by zaliczyć do priorytetowych dla tego typu organizacji. Wykazano bowiem, że $74,4 \%$ badanych NTO uznało działania podejmowane w ramach brandingu za jeden z głównych aspektów swojego funkcjonowania. Wyższe wartości odnotowano tylko w przypadku działań promocyjnych podejmowanych na rynkach zagranicznych (94\%) oraz działań w zakresie projektowania i wdrażania różnego rodzaju kampanii informacyjnych (82\%). Do innych zadań wskazanych przez badane NTO jako kluczowe należy również zaliczyć:

- podejmowanie działań w zakresie badania rynku turystycznego $(42,2 \%)$,

- wspieranie rozwoju produktów turystycznych $(41,0 \%)$,

- współpracę z lokalnymi i regionalnymi organizacjami turystycznymi $(27,7 \%)$,

- organizowanie szkoleń na rzecz edukacji turystycznej (26,5\%).

Przeprowadzona analiza umożliwiła również prezentację płaszczyzn wykorzystywania brandingu w praktyce. Wykazano m.in., że tego rodzaju działania podejmowane są przez większą część analizowanych organizacji (67). Stanowi to 80,7\% badanych NTO. Większością w tej grupie są organizacje funkcjonujące w Europie $(53,7 \%)$. W odniesieniu do ogólnej liczby badanych organizacji (83) większy udział odnotowano również w przypadku europejskich NTO (43,4\%). Natomiast wśród NTO, które nie podejmują działań w ramach brandingu (16), przeważającą część $(81,3 \%)$ stanowią podmioty działające poza Europą.

Badania wykazały, że zdecydowana większość analizowanych NTO (75 organizacji, 90,4\%) w kampaniach promocyjnych wykorzystuje produkty o charakterze markowym. W grupie tej większą część (50,7\%) stanowią europejskie NTO. Również w odniesieniu do ogólnej liczebności badanej próby nieznacznie większy udział mają narodowe organizacje turystyczne funkcjonujące w Europie $(45,8 \%)$. Nato-

${ }^{1}$ Podziału badanych podmiotów dokonano w oparciu o zalecenia UNWTO, która wyróżnia 5 głównych regionów turystycznych na świecie: Region Europejski, Region Amerykański, Region Azji i Pacyfiku, Region Afrykański oraz Region Bliskiego Wschodu [Tourism Highlights... 2015]. 
miast tylko 9,6\% organizacji (7) nie wykorzystuje produktów markowych w swych działaniach. W tej grupie przeważają pozaeuropejskie NTO.

Analiza umożliwiła ponadto zidentyfikowanie głównych rodzajów produktów markowych wykorzystywanych przez badane NTO. Badania przeprowadzone na grupie 75 organizacji wykazały, że najczęściej jako produkty markowe wykorzystywane są elementy środowiska przyrodniczego, które bardzo często stanowią główne walory danej destynacji $(66,7 \%)$. Na drugim miejscu wskazano organizowane eventy $(53,3 \%)$, na trzecim zaś - elementy kulturowe, zwłaszcza zabytki $(50,6 \%)$. W pierwszym i trzecim przypadku częściej tego rodzaju produkty promowały NTO pozaeuropejskie, natomiast w przypadku eventów - NTO funkcjonujące w Europie.

Analiza umożliwiła również określenie zasięgu geograficznego działań podejmowanych przez poszczególne NTO w ramach brandingu. Wykazano, że w zdecydowanej większości organizacji (58 - 86,6\%) tego typu działania mają zasięg ogólnoświatowy. Większą część w tej grupie stanowią organizacje działające w Europie (56,9\%). Również w odniesieniu do ogólnej liczby NTO wykorzystujących branding (67 organizacji) udział europejskich NTO jest większy (49,3\%). Natomiast tylko 13,4\% badanych NTO (9 organizacji) prowadzi działania brandingowe wyłącznie na rodzimym kontynencie. W tej grupie większą część stanowią organizacje pozaeuropejskie (66,6\%). Tak szeroki zakres działań podejmowanych w ramach brandingu przez większość badanych NTO może świadczyć o randze i dużym znaczeniu tego typu inicjatyw w budowaniu świadomości marki krajowego ORT w poszczególnych państwach.

W niniejszym artykule zaprezentowano branding jako pojęcie złożone, wieloaspektowe, które może być wykorzystywane zarówno przez przedsiębiorstwa, jak i destynacje turystyczne. Budowanie silnej marki krajowego ORT to proces długotrwały i złożony, obejmujący wiele rodzajów działań wykorzystujących w mniejszym lub większym stopniu założenia brandingu. Przeprowadzona analiza umożliwiła zidentyfikowanie głównych płaszczyzn wykorzystywania tego typu działań. Wykazano m.in., że wśród badanych NTO cele brandingu najczęściej realizowane są pod postacią sprawnie funkcjonującego systemu identyfikacji wizualnej (55 organizacji - $82 \%$ wskazań badanych NTO). W tej grupie nieznacznie większy udział mają organizacje pozaeuropejskie (52,7\%). Również w odniesieniu do ogólnej liczby NTO wykorzystującej branding (67) udział NTO zaliczonych do kategorii „,reszta świata" jest o 4,5 pp. większy niż organizacji europejskich.

W opinii badanych NTO innymi ważnymi płaszczyznami wykorzystania brandingu są:

- realizowanie kampanii promocyjnych (67,1\% wskazań),

- pozycjonowanie marki krajowego ORT $(61,2 \%)$,

- zdefiniowanie Unique Selling Proposition (50,7\%),

- monitorowanie wyników marki (49,3\%),

- realizacja różnego rodzaju kampanii świadomości (m.in. działania edukacyjne). 


\section{Zakończenie}

Zaprezentowane w artykule wyniki stanowią jedynie część przeprowadzonych przez autora kompleksowych badań dotyczących funkcjonowania 83 narodowych organizacji turystycznych. Analiza dotyczyła głównych obszarów działalności tego typu organizacji (badano m.in. aspekt prawno-organizacyjny, ekonomiczny oraz marketingowy). Jednak główną oś rozważań stanowił branding oraz najważniejsze płaszczyzny jego praktycznego wykorzystania.

Przeprowadzona przez autora analiza wykazała, że branding odgrywa bardzo ważną rolę w działaniach badanych NTO. Świadczy o tym fakt, iż przez 74,7\% analizowane NTO został uznany za jedną z trzech najważniejszych sfer działalności. Również wyniki badań dotyczące wykorzystywania brandingu w praktyce potwierdzają jego istotne znaczenie. Wykazano m.in., że tego rodzaju działania podejmowane są przez większą część analizowanych organizacji (67). Stanowi to 80,7\% badanych NTO. Wydaje się zatem, że przyjęta w artykule hipoteza badawcza została potwierdzona. Bez wątpienia branding jest jednym z kluczowych elementów walki konkurencyjnej destynacji turystycznych i odgrywa istotną rolę w całym procesie zarządzania obszarem recepcji turystycznej, pomimo że nie należy do głównych zadań, które w założeniach przypisuje się organizacjom typu NTO.

Według autora zaobserwowane zjawisko może stanowić przyczynek do dyskusji dotyczącej zrewidowania (np. rozszerzenia) zakresu podstawowych zadań przypisywanych narodowym organizacjom turystycznym. Analiza wykazała bowiem, że znaczną część aktywności tego typu organizacji stanowią działania związane z wykorzystywaniem brandingu, czyli z inicjatywami podejmowanymi na rzecz budowania i znajomości marki krajowej destynacji turystycznej w świadomości i umysłach potencjalnych turystów. Natomiast różnice pomiędzy organizacjami europejskimi i pozaeuropejskimi w zakresie postrzegania brandingu oraz mechanizmów jego wykorzystywania mogą świadczyć o jego wieloaspektowości i wciąż nie do końca zbadanych wymiarach. Jest to bowiem pojęcie stosunkowo nowe, którym dopiero od niedawna naukowcy zainteresowali się tak szeroko.

\section{Literatura}

Aaker D.A., 1991, Managing Brand Equity, Simon and Schuster, New York.

Aaker D.A., 1997, Dimensions of Measuring Brand Personality, Journal of Advertising Research, vol. 34 .

Aaker D.A., 2002, Building Strong Brands, Simon and Schuster, London.

Anholt S., 2002, Brand New Justice: The Upside of Global Branding, Butterworth-Heinemann Title, New York.

Anholt S., 2003a, Brand New Justice: How Branding Places and Products Can Help the Developing World, Elsevier Butterworth-Heinemann, Oxford. 
Anholt S., 2003b, Branding Places and Nations, [w:] Brands and Branding, The Economist in association with Profile Books Ltd, London.

Anholt S., 2005, Brand America - tajemnica mega marki, Instytut Marki Polskiej, Warszawa.

Anholt S., 2006 Competitive Identity: The New Brand Management for Nations, Cities and Regions, Palgrave Macmillan, London.

Anholt S., 2007, Tożsamość konkurencyjna. Nowe spojrzenie na markę, Instytut Marki Polskiej, Warszawa.

Anholt S., 2009, Places, Identity, Image and Reputation, Palgrave Macmillan, Londyn.

Anholt S., 2010, Great Brand Stories: Brand America, Marshall Cavendish, New York.

Anholt S., Spaven P., 2009, International Place Brand Yearbook, Palgrave Macmillan, Basingstoke.

Ashworth J.G., 2010, Towards Effective Place Brand Management: Branding European Cities and Regions, Edward Elgar Publishing Ltd., London.

Bieger T., 1998, Reengineering Destination Marketing Organisations - the Case of Switzerland, Institut für Tourismus und Verkehrswirtschaft, Universität St. Gallen, Switzerland.

Blain C., Levy S.E., Ritchie J.R.B., 2005, Destination Branding: Insights and Practices from Destination Management Organizations, Journal of Travel Research, vol. 43.

Borzyszkowski J., 2015, Organizacje zarządzajace obszarami recepcji turystycznej. Istota, funkcjonowanie, kierunki zmian, Wydawnictwo Politechniki Koszalińskiej, Koszalin.

Boyle D., 2003, Authenticity: Brands, Fakes, Spin and the Lust for Real Life, Flamingo, London.

Buhalis D., 2000, Marketing the Competitive Destination of the Future, Tourism Management, no. 21.

Butler R., 1980, The Concept of a Tourist Area Cycle of Evolution: Implications for Management of Resources, The Canadian Geographer, no. 24 (1).

Carter R., Fabricius M., 2007, Creating competitive advantage for your destination, UNWTO Conference 7 February, Budapest.

Cieślikowski K., Żemła M., 2002, Pozycjonowanie obszaru recepcji turystycznej z wykorzystaniem map percepcji, Marketing i Rynek, nr 2.

Cliffton R., Simmons J., 2004, Brands and Branding (1st ed.), Profile Book Ltd., London.

Davidson R., Maitland R., 1997, Tourism destinations, Hodder \& Stoughton, London.

de Chernatony L., McDonald M., 2003, Creating Powerful Brands, 3rd edition, Elsevier, Butterworth Heinemann, Oxford.

Dębski M., 2013, Jakość jako element budowania marki destynacji podczas kryzysu gospodarczego, Współczesne Zarządzanie, nr 1.

Dinnie K., 2008, Nation Branding: Concepts, Issues, Practice, Butterworth-Heinemann, Oxford.

Dinnie K., Fola M., 2009, Branding Cyprus - a stakeholder identification perspective, Accepted for 7th International Conference on Marketing, Athens Institute for Education and Research (ATINER), Athens, Greece.

Domański T. (red.), 1997, Marketing terytorialny. Strategiczne wyzwania dla miast i regionów, Centrum Badań i Studiów Francuskich, Uniwersytet Łódzki, Łódź.

Dziedzic E., 1998, Obszar recepcji turystycznej jako przedmiot zarzadzania strategicznego, Monografie i opracowania, nr 442, SGH, Warszawa.

Fan Y., 2006, Branding the nation: What is being branded?, Journal of Vacation Marketing, vol. 12.

Flagestad A., 2002, Strategic Sources and Organizational Structure in Winter Sport Destinations, PhD Dissertation, University of Bradford.

Flanagan S., Ruddy J. (eds.), 2000, Tourism Destination Marketing: Gaining the Competitive Edge, Dublin Institute of Technology, Dublin.

Gabrielsson M., 2005, Branding Strategies of Born Globals, Jourmal of International Entreprenuership, no. 3 .

Girard V., 1997, Marketing terytorialny i planowanie strategiczne, [w:] Domański T. (red.), Marketing terytorialny. Strategiczne wyzwania dla miast i regionów, Uniwersytet Łódzki, Łódź. 
Goncalves V.F.C., Aguas P.M.R., 1997, The Concept of Life Cycle, An Application to the Tourism Prod$u c t$, Journal of Travel Research, no. 4.

Govers R., 2009, From place marketing to place branding and back, Place Branding and Public Diplomacy, no. 7 (4).

Govers R., Go F., 2009, Place Branding: Global, Virtual and Physical Identities, Constructed, Imagined and Experienced, Palgrave Macmillan, Basingstoke.

Green S., 2005, Defining West London - A case study of the initial stages of a strategic place branding exercise, CoDesign, no. 1 (4).

Handbook on Tourism Destinations Branding, World Tourism Organization (UN WTO), 2009, European Travel Commission (ETC), Madrid, Spain.

Heath E., Wall G., 1991, Marketing Tourism Destinations: A strategic Planning Approach, Wiley, New York.

Inskeep E., 1994, National and Regional Tourism Planning, Routledge, New York.

Ipsas A., 2012, The Tourism Destinations Marketing - A Mandatory Course for the Students of Tourism, materiał w wersji elektronicznej, www.steconomice.uoradea.ro.

Kavaratzis M., Ashworth G., 2006, City Branding: an Effective Assertion of Identity or a Transitory Marketing Trick?, Journal of Place Branding, vol. 2, no. 3.

Kesić T., Pavlić I., 2011, Tourism Destination Image Formation - the Case of Dubrovnik, Croatia, Tržište, vol. XXIII, Faculty of Economics \& Business, University of Zagreb.

Kotler Ph., Haider D.H., Rein I., 1993, Marketing places, The Free Press, New York.

Kotler Ph., Bowen J., Makens J., 2003, Marketing for Hospitality and Tourism (3rd ed.), Upper Saddle River: Prentice Hall.

Kozak M., Mazurek M., 2011, Marka obszaru recepcji turystycznej: wartość marki, tożsamość marki, rozszerzanie marki i co-branding, Folia Turistica, $\mathrm{nr} 25$ (2).

Kozioł L., 2012, Typologia czynników motywujących do podróżowania, Zeszyty Naukowe Małopolskiej Wyższej Szkoły Ekonomicznej w Tarnowie, T. 20, Nr 1.

Leiper N., 2004, Tourism Management (3rd ed.), Frenchs Forest: Pearson Education Australia.

Łuczak M., 2010, Rola identyfikacji wizualnej w kreowaniu marki i aktywizacji obszaru turystycznego, Acta Scientiarum Polonorum Oeconomia, nr 9 (4), SGGW, Warszawa.

Majewski J., 2000, Technika kreowania marki w marketingu turystycznym, [w:] Szwichtenberg A., Deluga W. (red.), Rola marketingu w rozwoju regionów turystycznych, Politechnika Koszalińska, Koszalin.

Majewski J., 2007, Struktury organizacyjne dla brandingu produktów terytorialnych, Rocznik Naukowy Wyższej Szkoły Turystyki i Rekreacji im. M. Orłowicza w Warszawie, t. 6, Wyższa Szkoła Turystyki i Rekreacji im. M. Orłowicza w Warszawie, Warszawa.

Majewski J., 2012, Branding w zarzadzaniu popytem na turystykę wiejska, Zeszyty Naukowe Uniwersytetu Szczecińskiego, nr 698, Ekonomiczne Problemy Usług, nr 83, Szczecin.

Manente M., Minghetti V., 2006, Destination Management Organizations and Actors, [w:] Buhalis D., Costa C. (eds.), Tourism Business Frontier, Elsevier.

Markowski T., 1999, Zarzadzanie rozwojem miast, PWN, Warszawa.

Marczak M., 2013, Branding w turystyce - przykłady wykorzystania przez narodowe organizacje turystyczne w wybranych krajach, [w:] Gospodarka turystyczna w regionie. Rynek turystyczny wspótczesne trendy, problemy i perspektywy jego rozwoju, Prace Naukowe Uniwersytetu Ekonomicznego we Wrocławiu, nr 304, Wydawnictwo Uniwersytetu Ekonomicznego we Wrocławiu, Wrocław.

Mazurek M., 2008, Tourism Destination Branding: A Competitive Marketing Strategy - Does it really matter? A Case Study of Kremnica, Slovakia, Proceedings Of the 4th graduate Student research Symposium, Victoria, BC, Canada. 
Meffert H., 1989, Städtmarketing - Pflicht oder Kür?, Sympozjum „Stadvisionen”, Stadtstrategien und Städtmarketing in der Zukunft, Münster.

Middleton V.T.C., Hawkins R., 1998, Sustainable Tourism. A Marketing Perspective, Buttenworth-Heinemann, Oxford.

Morgan N. i in., 2004, Destination Branding: Creating the Unique Destination Proposition, 2nd edition, Elsevier Butterworth-Heinemann, Oxford.

Morrison A.M., 2013, Destination Management and Destination Marketing: The Platform for Excellence in Tourism Destinations, Tourism Tribune, no. 28 (1).

Murray C., 2001, Making Sense of Place: New Approaches to Place Marketing, Comedia, Nimes.

Nawrocka E., 2008, Wizerunek obszaru recepcji turystycznej, Zeszyty Naukowe Uniwersytetu Szczecińskiego, nr 521, Ekonomiczne Problemy Turystyki, nr 11, Szczecin.

Niezgoda A., 2006, Obszar recepcji turystycznej w warunkach rozwoju zrównoważonego, Prace Habilitacyjne, nr 24, Wydawnictwo Akademii Ekonomicznej w Poznaniu, Poznań.

Nowacki M., Zmyślony P., 2012, Segmentacja rynku turystycznego na podstawie pomiaru percepcji wizerunku miasta, [w:] Panasiuk A. (red.), Popyt turystyczny. Konsumpcja - Segmentacja-Rynki, Zeszyty Naukowe Uniwersytetu Szczecińskiego, nr 699, Ekonomiczne Problemy Usług, nr 84, Szczecin.

Olins W., 2000, Trading Identities: Why Countries and Companies Are Taking on Each Others' Roles, Foreign Policy Centre, London.

Olins W., 2004, Branding the Nation, In: OnBr@nd, Thames and Hudson, London.

Page S., Connell J., 2009, Tourism. A Modern Synthesis, Cengage Learning EMEA.

Palmer A., Bejou D., 1995, Tourism destination marketing alliances, Annals of Tourism Research, vol. $22(3)$.

Panasiuk A., 2014, Rynek turystyczny. Studium strukturalne, Difin, Warszawa.

Pike S., 2002, Destination Image Analysis - A Review of 142 Papers from 1973 to 2000, Tourism Management, vol. 23 , no. 5 .

Pike S., 2004a, Destination brand positioning slogans - towards the development of a set of accountability criteria, Acta Turistica, no. 16 (2).

Pike S., 2004b, Destination Marketing Organisation, An Integrated Marketing Communication Approach, MPuls, Zagreb.

Pike S., 2005, Beyond products brand management: Tourism Destination Branding Complexity, Journal of Product and Brand Management, no. 14 (4).

Pike S., 2008, Destination Marketing an Integrated Marketing Communication Approach, Butterworth-Heinemann is an imprint of Elsevier.

Pike S., 2009, Destination brand positions of a competitive set of near-home destinations, Tourism Management, no. 30.

Pike S., Page S., 2014, Destination Marketing Organizations and destination marketing: A narrative analysis of the literature, Tourism Management, no. 41.

Rausch A., 2009, Capitalizing on Creativity in Rural Areas: National and Local Branding in Japan, Journal of Rural and Community Development, no. 4 (2).

Richie J.B., Ritchie R.J.B., 1998, The Branding of Tourism Destination: Past Achievements and Future Trends, Reports of 48th Congress, AIEST, St-Gall.

Saraniemi S., Ahonen M., 2008, Destination Branding from Corporate Branding Perspective, Proceedings of the Conference on Corporate Communication 2008, June 6th-9th, Wroxton, England.

Szromnik A., 1997, Marketing terytorialny - geneza, rynki docelowe i problemy oddziaływania, [w:] Domański T. (red.), Marketing terytorialny, Strategiczne wyzwania dla miast i regionów, Uniwersytet Łódzki, Łódź.

Szromnik A., 2002, Marketing terytorialny - koncepcja ogólna i doświadczenia praktyczne, [w:] Markowski T. (red.), Marketing terytorialny, Polska Akademia Nauk, Komitet Przestrzennego Zagospodarowania Kraju, Warszawa. 
Tan A.J.S., 2008, Destination Branding: Creating a Destination of Choice, Perspectives in Asian Leisure and Tourism, vol. 1 (1).

Tesławski M., 2013, Praktyka brandingu, Wydawnictwo „Słowa i Myśli”, Lublin.

Tourism Highlights, 2015, Edition, UNWTO, Madrid.

Ward S.V., 1998, Selling Places: The Marketing of Towns and Cities, 1850-2000, Routledge, London.

Żemła M., 2003, Podstawy formułowania strategii kształtowania produktu turystycznego regionu, Górnośląska Wyższa Szkoła Handlowa im. Wojciecha Korfantego, Katowice.

Żemła M., 2009, Nowe zastosowania marki jako narzędzia w marketingu produktu obszarów recepcji turystycznej, [w:] Gospodarka turystyczna w regionie Przedsiębiorstwo. Samorząd. wspótpraca, Prace Naukowe Uniwersytetu Ekonomicznego we Wrocławiu, nr 50, Wrocław.

Żemła M., 2012, The idea of destination brand licensing and the question of its effectiveness, Tourism and Hospitality Management, vol. 18, no. 2. 